ISSN 0258-7122

Bangladesh J. Agril. Res. 34(2) : 233-238, June 2009

\title{
EFFECT OF PLANT GROWTH REGULATORS ON GROWTH AND YIELD OF MUKHI KACHU
}

\author{
MD. MOSLEH UD-DEEN ${ }^{1}$
}

\begin{abstract}
An experiment was conducted with different concentrations of plant growth regulators to evaluate their effects on the growth and yield of late planted Mukhi Kachu (CoIocsis esculenta). Different treatments of uniconazole (growth retardant showed significant influence on plant height, petiole length, number of leases per plant, weight of leaf and weight of petioles per hill, number and weight of corms and cormels per hill and yield of cormel. $\mathrm{GA}_{3}$, (growth promoter) enhanced foliage growth, flowering, and cormel development
\end{abstract}

Key Words: Growth regulators, Mukhi Kachu (Colocusis esculenta) and yield.

\section{Introduction}

Mukhi Kachu (Colocasia esculenta) is known as taro, cocoyam, eddoe, and dasheen in different places and used as an important vegetable in various parts of the tropics (Onwueme, 1978). In Bangladesh, it comes to market as an important summer vegetable when most of the vegetables are not available. But the yield of Mukhi Kachu is quite low (6.5 t/ha) BBS, 2001) as compared to that of other countries (Onwueme, 1978). The crop grown under rainfed condition and it is planted in late summer when rainfall occurs. As a result, the crop gets short duration to complete its life cycle due to late plantation, which is one of the main causes of low yield of Mukhi Kachu in Bangladesh. Onwueme (1978) stated that Mukhi Kachu is a warm weather crop requiring an average daily temperature of $21^{\circ} \mathrm{C}$. After plantation, the crop requires first six months for shoot growth. Then it declines and cormel growth starts and continues to grow about 2-3 months till maturity, in this condition 8-9 months are required for a crop growing season for Mukhi Kachu. In our country, the plantation depends on rainfall that leaves short time for its growth and development. As a result, shoot growth is fully achieved but cormel growth does not, so yield decreases. In such a situation, any means that could reduce shoot growing period and enhance the early initiation of underground parts (corm and cormel) would be a great help for late planted crop. In this case, application of growth retardant would play an important role, which showed effective results in other crops (Rahim, 1988; Rahim and Alamgir, 1995; Ud-Deen et al., 2005). A growth promoter $\left(\mathrm{GA}_{3}\right)$ was also included in this study to confirm the effects of growth retardant.

\footnotetext{
${ }^{1}$ Department of Crop Science \& Technology, University of Rajshahi, Rajashahi-6205, Bangladesh.
} 


\section{Materials and Method}

The experiment was conducted in the experimentatal field of Rajshahi University, Rajshahi. The seed cormel of Mukhi Kachu variety Bilashi was used as experimental material. The land was medium high having sandy loam textured soil with pH 6.5 under the low Ganges river flood plain of agroecological zone AEZ 12. Two separate experiments were conducted. One with uniconazole (Sumiseven), a growth retardant comprising 3 (three) concentrations, such as

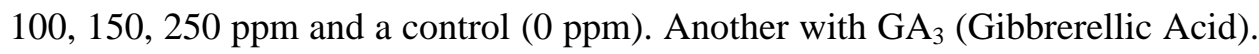
a growth promoter having same concentrations. Both the experiments were laid out in Randomized Complete Block Design (RCBD) with 3 replications. The unit plot size was $5 \mathrm{~m} \times 2.1 \mathrm{rn}$ and the plant spacing was $70 \mathrm{~cm} \times 50 \mathrm{~cm}$. The crop received 110 tons cowdung, $140 \mathrm{~kg}$ urea, $100 \mathrm{~kg}$ TSP, and $120 \mathrm{~kg}$ MP per hectare. Cowdung and TSP were applied before plantation and urea and MP were top dressed in two equal installments at 40 and 90 days after planting. Seed cormels were dipped in the respective concentrations of each growth regulators for 12 hours before planting. The crop was harvested at 90, 120, and 150 days after planting (DAP) to study their growth pattern and yield.

\section{Results and Discussion}

\section{Effects of uniconazole}

Uniconazole treated plants produced shorter plants with shorter petioles. A gradual decrease in plant height and petiole length for all the treatments was noticed as compared to that of control (Table 1). The tallest plant and petiole length were recorded in the control $\left(\mathrm{T}_{0}\right)$ plants, whereas the shortest one as found in plants treated with uniconazole of $250 \mathrm{ppm}$. Like plant height, a gradual decreasing trend in leaf number per plant, weight of leaves and petioles per hill were observed for all the treatments compared to that of control (Table 1). Higher concentration of uniconazole $(250 \mathrm{ppm})$ treated plants produced minimum leaf number per plant, weight of leaves per hill, and weight of petioles per hill, whereas the control $\left(\mathrm{T}_{0}\right)$ plants produced the maximum leaf number per plant, weight of leaves per hill, and weight of petioles per hill. Several authors reported that uniconazole resulted in a significant decrease in plant height of different crops (Barrett and Nell, 1992; Starman, 1991; Wang and Blessington, 1990; Henry, 1985; Davis et al., 1988; Deneke et al.,1992 and Keever and West, 1992). Frymire and Cole (1992), Henderson and Nichols (1991) and Norcini and Knox (1989) stated that uniconazole with medium drench applications reduced leaf area and leaf number, stem, and root dry weight. The above findings are in agreement with the present investigation. 
Significant differences were observed among different concentrations of uniconazole in respect of number of corms and cormels per hill, weight of corms and cormels per hill and finally yield (Table 1 and Figure 1-2). The highest number of corms per hill, cormels per hill, weight of corms per hill, cormels per hill and higher yield (6.90 kg/plot and $7.53 \mathrm{t} / \mathrm{ha})$ was found in the plants treated with $150 \mathrm{ppm}$ uniconazole, whereas uniconazole of $250 \mathrm{ppm}$ produced lowest number of corms per hill, cormels per hill, and weight of corms per hill, but control plants $\left(\mathrm{T}_{0}\right)$ produced the lowest weight of cormels per hill and lowest yield (3.75 kg/plant and $4.00 \mathrm{t} / \mathrm{ha})$. Uniconazole produced higher yield possibly by enhancing the translocation of assimilates downward, this enhanced the cormels development in this case by determining the position of metabolic sink. It may revealed that the physiological role played by the growth retardant would be similar to that of abscisic acid in controlling tuberzation in Dahlia (Halvey and Biran, 1975). The same fact was also supported by Knypl $(1979,1990)$ in onion; Rahim (1988) in garlic and Rahim and Alamgir (1995) in Mukhi Kachu. By using different growth retardants and gibberellic acid, Knypl (1979) and Rahim (1988) found that the growth retardants significantly increased bulb growth relative to the both control and gibberellic acid treated plants. Similar type of action was observed in the present study.

\section{Effects of $\mathrm{GA}_{3}$}

$\mathrm{GA}_{3}$ treated plants produced longer plants with longer petiole as compared to that of control (Table 2). As the concentration of $\mathrm{GA}_{3}$ increased the plant height, petiole length, number of leaves per plant and weight of leaves per hill and weight of petioles per hill also increased. Higher concentration of $\mathrm{GA}_{3}(250 \mathrm{ppm})$ treated plants produced maximum plant height, petiole length, number of leaves per plant, weight of leaves per hill, and weight of petioles per hill, whereas control $\left(\mathrm{T}_{0}\right)$ plants produced the minimum plant height, petiole length, number of leaves per plant, weight of leaves per hill, and weight of petioles per hill. However, the present findings agreed well with the findings of different workers, Mishriky et al. (1990) observed that $\mathrm{GA}_{3}$. significantly increased stem length and number of leavses per plant, while CCC (a growth retardant) reduced all these parameters of vegetative growth in pea. Ud-Deen et al. (2005) reported that number of leaves per plant, pseudostem length, leaf length, and plant height were increased with the increase of the duration of treatment of growth promoting hormone $\mathrm{CA}_{3}$. 
Table 1. Effects of uniconaoIe on the growth and yield of Mukhi Kachu (Colocusia esculenta).

\begin{tabular}{|c|c|c|c|c|c|c|c|c|c|c|c|}
\hline \multirow[t]{2}{*}{ Treatment } & \multirow{2}{*}{$\begin{array}{l}\text { Plant } \\
\text { height } \\
(\mathrm{cm})\end{array}$} & \multirow{2}{*}{$\begin{array}{c}\text { Petiole } \\
\text { length } \\
(\mathrm{cm})\end{array}$} & \multirow{2}{*}{$\begin{array}{c}\text { No. of } \\
\text { leaves/ } \\
\text { plant }\end{array}$} & \multirow{2}{*}{$\begin{array}{c}\text { Wt. of } \\
\text { leaves/ hill } \\
\text { (plant) }\end{array}$} & \multirow{2}{*}{$\begin{array}{c}\text { Wt. of } \\
\text { petioles/ } \\
\text { hill (g) }\end{array}$} & \multirow{2}{*}{$\begin{array}{c}\text { No. of } \\
\text { corms/ } \\
\text { hill }\end{array}$} & \multirow{2}{*}{$\begin{array}{c}\text { No. of } \\
\text { cormels/ } \\
\text { hill }\end{array}$} & \multirow{2}{*}{$\begin{array}{l}\text { Wt. of } \\
\text { corms/ } \\
\text { hill (g) }\end{array}$} & \multirow{2}{*}{$\begin{array}{c}\text { Wt. of } \\
\text { cormels/ } \\
\text { hill (g) }\end{array}$} & \multicolumn{2}{|c|}{ Yield of cormel } \\
\hline & & & & & & & & & & $\mathrm{kg} / \mathrm{plot}$ & t/ha \\
\hline $\mathrm{T}_{0}$ & 45.20 & 37.50 & 18.33 & 19.62 & 60.72 & 2.12 & 18.99 & 60.94 & 150.60 & 3.75 & 4.00 \\
\hline $\mathrm{T}_{100}$ & 41.86 & 35.10 & 16.90 & 12.53 & 53.60 & 1.85 & 23.33 & 75.33 & 190.66 & 6.03 & 6.76 \\
\hline $\mathrm{T}_{150}$ & 40.63 & 37.85 & 12.22 & 12.23 & 50.41 & 2.98 & 25.36 & 100.26 & 200.36 & 6.90 & 7.75 \\
\hline $\mathrm{T}_{200}$ & 36.15 & 30.52 & 9.36 & 8.36 & 40.12 & 1.20 & 18.89 & 60.60 & 195.55 & 4.96 & 5.68 \\
\hline LSD (5\%) & 3.06 & 2.12 & 1.09 & 4.36 & 4.89 & 0.66 & 4.85 & 8.69 & 7.55 & 2.36 & 1.36 \\
\hline
\end{tabular}

Table 2. Effect of $\mathrm{GA}_{3}$ on the growth and yiled of Mukhi Kachu (Colocasia esculenta).

\begin{tabular}{|c|c|c|c|c|c|c|c|c|c|c|c|}
\hline \multirow[t]{2}{*}{ Treatment } & \multirow{2}{*}{$\begin{array}{l}\text { Plant } \\
\text { height } \\
(\mathrm{cm})\end{array}$} & \multirow{2}{*}{$\begin{array}{l}\text { Petiole } \\
\text { length } \\
(\mathrm{cm})\end{array}$} & \multirow{2}{*}{$\begin{array}{c}\text { No. of } \\
\text { leaves/ } \\
\text { plant }\end{array}$} & \multirow{2}{*}{$\begin{array}{c}\text { Wt. of } \\
\text { leaves/ hill } \\
\text { plant }\end{array}$} & \multirow{2}{*}{$\begin{array}{c}\text { Wt. of } \\
\text { petioles/ } \\
\text { hill (gm) }\end{array}$} & \multirow{2}{*}{$\begin{array}{l}\text { No. of } \\
\text { corms/ } \\
\text { hill }\end{array}$} & \multirow{2}{*}{$\begin{array}{c}\text { No. of } \\
\text { cormels/ } \\
\text { hill }\end{array}$} & \multirow{2}{*}{$\begin{array}{c}\text { Wt. of } \\
\text { corms/ } \\
\text { hill (gm) }\end{array}$} & \multirow{2}{*}{$\begin{array}{c}\text { Wt. of } \\
\text { cormels/ } \\
\text { hill (gm) }\end{array}$} & \multicolumn{2}{|c|}{ Yield of cormel } \\
\hline & & & & & & & & & & kg/plot & t/ha \\
\hline $\mathrm{T}_{0}$ & 43.55 & 34.23 & 11.12 & 9.36 & 35.22 & 4.12 & 25.30 & 90.63 & 150.36 & 5.36 & 5.10 \\
\hline $\mathrm{T}_{100}$ & 46.33 & 37.54 & 12.99 & 11.23 & 49.66 & 3.65 & 23.10 & 81.23 & 189.55 & 6.56 & 6.12 \\
\hline $\mathrm{T}_{150}$ & 46.93 & 38.10 & 15.36 & 14.11 & 55.23 & 3.10 & 22.36 & 79.31 & 173.33 & 6.49 & 6.00 \\
\hline $\mathrm{T}_{200}$ & 48.66 & 40.93 & 19.23 & 15.47 & 65.36 & 2.35 & 14.23 & 65.33 & 135.35 & 4.98 & 4.35 \\
\hline LSD (5\%) & 5.36 & 2.03 & 5.61 & 3.10 & 7.56 & 2.02 & 4.03 & 9.36 & 5.36 & 1.03 & 2.36 \\
\hline
\end{tabular}


A decreasing trend was observed with increasing concentration of $\mathrm{GA}_{3}$ in relation to yield and yield contributing characters compared to that of control at different days after planting (Table 2 and Fig. 3-4). The control plants $\left(\mathrm{T}_{0}\right)$ produced the maximum number of corms per hill, cormels per hill, and weight of corms per hill, whereas $\mathrm{GA}_{3}$ of $250 \mathrm{ppm}$ treated plants produced the minimum number of corms per hill, cormels per lull, and weight of corms per hill. 100 ppm $\mathrm{GA}_{3}$ treated plants produced the highest cormel weight per hill and yield, but higher concentration of $\mathrm{GA}_{3}(250 \mathrm{ppm})$ produced the lowest cormel weight per hill and yield. It means $\mathrm{GA}_{3}$ enhanced vegetable growth of plants and did affect yield. $\mathrm{GA}_{3}$ enhanced flowering in Colocasia esculenta. Percent of flowers were increased with increase in concentration of $\mathrm{GA}_{3}$ upto $150 \mathrm{ppm}$ upto 90 days after planting (Fig. 5). It is supported by Miazaki et al. (1986). They stated that inflorescence contained flower and florets, but no pollen was formed from gibberellic acid induced inflorescence. Katsura et al. (1986) also reported that gibberellic acid induced flower in Colocasia esculenta rapidly. So, yields decreased due to application of gihberellic acid.

\section{References}

Barrett, J. E. and T. A. Nell. 1992. Efficacy of paclobutrazol and uniconazole on four breeding plant species. Hort. Sci. 27(8): 896-897.

BBS, 2001. Year Book of Agricultural Statistics of Bangladesh. Bangladesh Bureau of Statistics, Statistics Division, Ministry of Planning, Government of People's Repub lic of Bangladesh, Dhaka, Bangladesh. pp. 105.

Davis, T. D., G. L. Steffens and N. Sankhla. 1988. Triazole plant growth regulators. In: Janick J. (ed.) Hrt. Reviews, Vol. 10.Timber press, Porttand, Oregen, pp. 63-105.

Deneke, C. F., P. F. Thomas and G. J. Keever. 1992. Uniconazole restricts growth of seed propagated Physostegia virgeniana (L.) Benth. "Alba” Hort. Sci. 27(8): 129-132.

Frymire, R. M. and J. C. Cole. 1992. Effect of Uniconazole on growth and chlorophyll content of Pyracanthe, Photinia and dwarf Burford holly. J. Plant Growth Regul. 11: 143-148.

Halvey, A. H. and I. Biran. 1975. Hormonal regulation of tuberi8zation in Dahlia. Acia Horti. 47: 319-329.

Henderson, J. C. and T. H. Nichols. 1991. Pyracantha caecinea "Kasan" and "Lalandei" response to uniconazole and chlormequat chloride. Hort. Sci. 26: 877-880.

Henry, M. J. 1985. Plant growth regulating activity of sterol and gibberellin biosynthesis inhibitors. Plant Growth Regul. Soc. Am. 13: 9-11.

Katsura, N., K. Takayanagi and T. Sato. 1986. Gibberellic acid induced flowering in cultivars of Japanese taro. J. of the Japanese Soc. of Hort. Sci. 55(1): 69-74.

Keever, G. J. and M. S. West. 1992. Response of established landscape plants to uniconazole. Hort. Tchno. 2(4): 465-468. 
Knypl, J. S. 1979. Increasing bulb growth in onion with growth retardants and reversal of the effect by gibberellic acid. Plant Sci. Letters 14: 193-198.

Knypl J. S. 1990. Stimulation of bulb growth in onion (Allium cepa) by N-diethyl-N-(2hydroxyethyl) glycine. Biologia Plantarum 22(3): 226-230.

Mishriky, J. F., K. A. Fadaly and M. A. Badawi. 1990. Effect of gibberellic acid $\left(\mathrm{GA}_{3}\right)$ and chlormequat (CCC) on growth, yield and quality of peas (Pisum sativum L.). Bulletin of Faculty of Agriculture, University of Cairo, Giza, Egypt. 41(3): 785-797.

Miyazaki, S., Y. Tashiro, K. Kanozowa and M. Tabaru. 1986. Promotion of flowering of taro by the treatment of seed cormel and young plants with gibberellic acid. J. of the Japanese Soc. of Hort. Sci. 54(4): 450-549.

Norcini, J. G. and G. W. Knox. 1989. Response of Ligustrum x Ibolium, Photinia x fraseri and Pyracantha koidzumii "wonder berry" to XE-1019 and pruning. J. Environ. Hort. 7: 126-128.

Onwueme, I. C. 1978. The tropical Tuber Crops. John Wiley \& Sons. Chichester. pp. 234.

Rahim, M. A. 1988. Control of growth and bulbing of garlic (Allium sativum L.). Ph. D. Thesis, University of London, pp. 203.

Rahim M. A. and M. Alamgi. 1995. Effect of paclobutrazol and gibberellic acid on the growth of late planted Mukhi Kachu (Colocasis esculenta). Progressive Agriculture 6(1): 39-46.

Starman, T. W. 1991. Lisianthus growth and flowering response to uniconazole. Hort. Sci. 26: 150-152.

Ud-Deen, M. M., G. Kabir, M. A. Rahman and M. S. Hossain. 2005. Influence of plant growth regulators on morphological changes in onion (Allium ceoa L.). Bangladesh. J. of Environ. Sci. 11(1): 94-96.

Wang. Y. T. and T. M. Blessington. 1990. Growth of four tropical foliage species treated with paclobutrazol or uniconazole. Hort. Sci. 25(2): 202-204. 